\title{
Popular Art Forms in the DRC
}

\section{Practices and Peripheries}

\author{
Françoise Naudillon | ORCID: 0000-0002-5961-7043 \\ Concordia University, Montréal, QC, Canada \\ francoise.naudillon@concordia.ca
}

\begin{abstract}
Popular literary forms have experienced a remarkable vitality in the Democratic Republic of the Congo. While it is difficult to define popular literature, it is necessary to recognize within Francophone literature the existence of types of texts that escape the attention of both discursive and institutional practices of legitimization, texts that are consigned to the margins of the dominant literary canon. In fact, these texts transgress the conventions of these literary "sub-genres," such as detective novels, dime novels, exoticist novels, novels of manners, as well as graphic novels or comics. The success of Zamenga Batukezanga (1933-2000), still the most widely read and recognized writer in the DRC, as well as the recent rise of comic book writer Jérémie Nsingi, the author of many fanzines and small-run comic strips, reflect how these genres reconstruct canons and illustrate the emergence of a popular social imaginary.
\end{abstract}

\section{Keywords}

popular literatures - detective novel - comic book - DRC

National literature does not mean much these days; now is the age of world literature, and everyone must contribute to hasten the arrival of that age.

JOHANN WOLFGANG VON GOETHE 
The Democratic Republic of the Congo (DRC) sings a unique song of many voices in the global chorus of literatures. We can hope that the time is over when any writer and their works were consigned to the cultural fringes far from the de facto center in the West. Thinking about world literature has evolved. While many critics agree that Goethe is the father of the notion of Weltliteratur (Goethe 1999), in order to translate to contemporary times the existence of a global regime of literature, it is necessary to also acknowledge David Damrosch (2003), Edward Said (1980), Franco Moretti (2000), and Pascale Casanova (1999) - but especially Édouard Glissant and the Tout-monde (1997) - in order to understand world literatures' evolution and implications.

Furthermore, as Gesine Müller explains (2014), we must bear in mind the two poles of world literature and Littérature Monde. On the one hand, there is the valorization in Littérature Monde of multilingualism, while theorists of world literature privilege the role of translation. On the other hand, there is praise for the periphery in Littérature Monde, while thinking for world literature begins from a European literary perspective. Then again, Littérature Monde understands better the nomadic character of writing, which allows the deployment of a different cultural imaginary in the heart of the Center. While these two conceptions are antithetical, the "supremacy of European criticism" (Müller, 69) in literary criticism and in the formation of canons remains constant. Nevertheless, the dynamics of the local and the global must remain at the center of all discourse about contemporary literature. In this way, the literary scenes of the DRC offer an interesting paradox.

Francophone African literatures have acquired an increasingly important place in scholarship and teaching under the labels of "minor," postcolonial, or Francophone literature. If these theoretical rubrics have accompanied and even favored the institutionalization of Francophone literature, at the same time they raise problems that invite us to return to the processes of legitimization. The Francophone literary canon of sub-Saharan Africa, North Africa, and the Caribbean - which brings together the most popular works, the most taught work, and those that generate the lion's share of scholarship - has a corollary margin made up of works that are of similar importance but that are local or regional. Thus there exist Francophone texts that escape the attention of both discursive and institutional practices of legitimization, texts consigned to the margins of the dominant literary canon. These are the texts of popular literature and paraliterature, as well as those popular cultural forms not recognized by institutions and so-called educated society. 
Officially, popular genres are apparently in bad taste. In Francophone literature, next to the impressive monuments erected to honor Aimé Césaire, Mohamed Deb, or Ahmadou Kourouma, hundreds of African writers are ignored - that is to say, they are scorned and relegated to obscurity. As plants need a rich mix of compost to grow, are what we call literary "masterpieces" dependent upon other works, which are either self-published, suspected of plagiarism, cheaply put together, and belong to genres considered to be hardly literary, such as detective novels, science fiction, and love stories?

Coincidentally, this marginalization has a paradoxical result: in these popular texts, processes of hybridization and decentering transform literary canons. In fact, these texts transgress the conventions of the literary sub-genres of the detective novel, romance novel, exotic novel, adventure novel, and so on genres that share an intergeneric connection and a reciprocal influence with novels, plays, and films. Often published by short-lived publishing ventures or often self-published, these works escape the attention of the critic, but are, paradoxically, widely read and consumed by the publics they address. Indeed, we are witnessing the increasingly complex emergence of a popular readership in Francophone spaces. In works intended for a local public, local authors adapt fictional and narratological schemas to take into account local color (think of love stories). These phenomena ask for our consideration, since, as Damrosch writes, "for any given observer, even a genuinely global perspective remains a perspective from somewhere, and global patterns of the circulation of world literature take shape in their local manifestations" (27).

As Karin Barber writes in her last book, A History of African Popular Culture:

Popular culture in Africa is a product of everyday life. It is the unofficial, the non-canonical. It is usually taken to mean the culture of 'ordinary people': not the educated elites, politician, military top brass and rich businessmen; not the people in power, the people who have legal or illegal bank accounts in Switzerland and send their children to boarding schools overseas; but rather petty traders, primary school teachers, taxi drivers, farmers, the unemployed, street children, in the Congo.

1

At the same time, in Africa in general and in the Congo, social classes are not fixed and evolve according to economic and political circumstances: 
Members of an elite group almost always have poor relatives [...] Subjectively as well as objectively, the boundaries of social strata are fluctuating and indeterminate $[\ldots]$ The culture participated in by privileged sections of society and shot through with cross-currents; not a mere clone of metropolitan models [...], a process which has often involved incorporating popular materials rather than holding them at arm's length.

10

Usually, derogatory terms condemn popular literatures as being in bad taste or being out of date, seeing as how in France these genres are associated historically with the rise of serialized novels in the nineteenth century. Yet in his article "Modernités littéraires en Afrique: injonction ou évidence," Xavier Garnier writes of how modernity defined popular writing at the end of the colonial era:

From the end of the colonial era, the problem for a large number of modern artists in Africa was finding the means by which to contact the African masses once, for better or for worse, oral traditions were excluded from the sphere of the modern. In oral traditions, there is a concern about the modern, but that gets channeled directly into the use of technologies such as the radio and the Internet. ${ }^{1}$

90

Reaching the masses takes place through another technology: film, which allows the artist a way to express himself or herself in the language of the people. This can be seen in the work of the Senegalese Sembene Ousmane. Now that literacy rates have increased remarkably since African nations became independent, the question of orality has ceded to another challenge: the multiplicity of languages present in the same geopolitical space. In the case of the DRC, there are several languages in circulation beyond French: Lingala (in the West), Swahili (in the East), Kikongo, and Tshiluba - all four of which are national languages. Popular art forms must grow out of this linguistic plurality and develop their distribution platforms with this linguistic backdrop in mind.

As a consequence, today, as Stephanie Newell and Onookome Okome state:

[...] popular art cannot be regarded any longer by scholars as the vehicle for a singular, albeit emergent class consciousness, nor discussions of

1 All translations from the French are mine. 
African popular art forms need to revolve around the extent to which producers are participants in global processes of capitalist consumption or, conversely, as resistant local appropriators of worldwide materials.

18

But beyond the question of how technology spreads popular forms of art, it is necessary to recognize, as Garnier (2009) points out, "if there is a modernity to popular literature in Africa, it is in its capacity to participate in social debates circulating among the modern masses." (89) Thinking about what constitutes modernity has changed: no longer is it a matter, as in the colonial era, of transcribing stories, legends, or myths from the oral tradition, but of putting in place a modernity and a specifically African identity. Tirthankar Chanda's recent article celebrating the Senegalese David Diop's novel Frère d'âme, selected as the Prix Goncourt des Lycéens, gestures to this revolution: "French-language African literature is spreading like wildfire, with its authors regularly being awarded the top French literary prizes, and whose books are flying off the shelves. Africa is today one of the major sources of Francophone writers" (2019).

Widespread recognition is today correlated to commercial success, which is itself derived, at least in the French marketplace, from literary prizes, leading to sales of 250,000 copies or more. But it is necessary to distinguish between this organized consecration of legitimacy from what takes place outside of Paris that is, in Africa. Because everyone feel that the literary recognition bestowed through official Parisian modalities does not extend to the countries in which the authors were born. It is a deplorable situation:

[...] the distribution of books in the Francophone world does not take place in any organized way, which made the Congolese author Henri Lopès remark that "the people for whom I write aren't interested in me." The reality is that books published in France are too expensive for Africans and that, as a result, Africans are deprived of their most representative writers.

CHANDA 2019

So, the notion of popularity addresses two realities that coexist but that do not communicate with each other. While Francophone authors such as Fatou Diome, Ahmadou Kourouma, Cheikh Hamidou Kane, and Mariama Bâ are at the head of the list of the 443 African books sold at FNAC ("Meilleurs ventes"), the reputations of these writers in Europe exceed their reputations in Africa. 
The DRC is an excellent case study because it has inherited cultural structures from colonization (for example, the publisher Mediapaul) but also boasts of relatively autonomous regional networks operating within fragile politicoeconomic formations. Moreover, as is the case in many Francophone African countries, the best-known Congolese authors are published in former colonial capitals such as Paris or Bruxelles. Christophe Cassiau-Haurie has spoken about this impasse:

[...] the Congolese writer is at an impasse: not read in the DRC due to the enormous problems of distribution, of the impossibility of "mediazation," and of the unknown dimensions of readership, the writer is not read as well in the West, excluded from Parisian publishing due to the writer's "Belgian" character.

2007

Popular literatures and paraliteratures take advantage of this situation in several ways: they invent readers and reading habits; they create horizons of aspiration and bring about a certain faithfulness on the part of readers who recognize a literary product created for them, in their image; and they open the debate about collective sociocultural realities that oppose the clichés and other discourse produced in the West. The novels at the top of the FNAC list do not appear, at first glance, to be those on the horizon of aspiration of the average young Congolese in Kinshasa whose life is defined by the daily resourcefulness that poverty has forced upon him or her. Many other publications, however, escape the attention of FNAC or other international distributors of African books. But which publications are we talking about? Gabonese blogger Izuwa presents a list that is very different from FNAC's; she calls it "underground African literature" (2019). She defines underground African literature as "works that are self-published or published by relatively unknown publishing houses that have their own distribution networks, their own promotional events, and their own players and habits" (2019).

\section{Cultural Underground in Africa}

\subsection{Afrocentrism}

Izuwa notes the special importance of the Afrocentrist movement, defined as "an ideology that wants to force the African to rethink Africa and the World according to a paradigm that is its own," including the Khemetic Nation. ${ }^{2}$

2 Kemetism, or Khemetism, is a religious movement founded in the USA in the 1970s and 
With this position comes the logical corollary that authors of this stripe refuse to be published or to conform to the will of the "classical" publishers of the former colonial capitals. They self-publish or share their reflections via vlogs, blogs, online videos, YouTube channels, Internet sites, or other alternative means of communication. Several publishers are nevertheless recognized in the Afrocentrism movement, such as MeduNeter, associated with the panAfrican bookseller Tamery; La clé des couleurs; Anyjart; and Dagan, founded by Dieudonné Gnammankou, the African historian, which publishes authors such as Kama Kamanda and Doumbi Fakoly, among others. Their collective effort is to create a book industry separate from Western dictates.

\subsection{The Chronicles}

The second trend noted by Izuwa is The Chronicles, narratives published on Facebook by women that appear periodically and consist of several pages per publication. Some of these chronicles already number 150 entries. Born in the 2010s, The Chronicles are first and foremost love stories, romance novels, whose subscribers (the Chronicosphere) wait impatiently for each new issue. The number of subscribers for an issue can be anywhere from tens of subscribers to thousands. More recently, in 2015, Muswada - an application dedicated to reading communities, created by the Beninese Adolphe Anianou Gbo - can mobilize 300,000 readers every month. One of the most prolific contributors is Lily Rose Agnouret, who has totaled 677,264 site visits for her stories. Her work can now be found on Amazon, with thirty-six titles ranging from four to six euros in price. To Izuwa's two categories, I will add three others, which explore other genres and literary networks. I will limit myself to speaking of Congolese work.

\subsection{Detective Novels}

Of course, the Congolese detective novel has long been acknowledged for its brilliance. Its practitioners include Achille Ngoye, Désiré Bolya Baenga, and In Koli Jean Bofane, to name just a few. But the popularity of the African detective novel reached new heights when in 2018 the Salon du Livre in Paris opened a space dedicated to the Black novel, with Africa featured prominently. There, Janis Otsiemi, Gabonese author of Tu ne perds rien pour attendre (2017), was compared to James Ellroy; he declared that Africa is nothing less than an "endless detective novel." (Hélène)

inspired by the former religions of Pharaonic Egypt. Kemet, which can be translated as "Black land" or "country of the Blacks," advocates either a return to the religion of Aton or polytheism. Khemites are, for the most part, Afrocentrists. 
Beyond official recognition, the reception of texts is more problematic. The genre of the African detective novel is well established. From the success of Abasse Ndione, who published his first novel La Vie en spirale in the 1990s; or that of Malian author Moussa Konaté (1951-2013), considered the progenitor of the African ethno-detective novel; or the establishment in February 2000 of the first "Polar à Dakar" Festival - all of these markers point to the African detective novel as being a fait accompli. But, as I have written about elsewhere, the rules of the African detective novel are different from those of the Western canon because their plots often introduce elements of sorcery or magic to the deductive method of the Western narratives - the protagonists must conform to the social order that derives from a mystical order (Naudillon 2003). Finally, consider the aforementioned Achille Ngoye, who was a journalist before becoming an author of detective novels and, along with the illustrator Denis Boyau, was one of the founders in the 1970 of the magazine Jeunes pour jeunes, with its zany illustrations and comic strips. This summary bears witness to the extreme porosity of so-called popular genres and cultures: artists can be, in effect, actively engaged in several domains, from the novel to the theater, from comics to music. This is the case, for example, in the expansive network of works categorized as Afrofuturist.

\subsection{Afrofuturism}

Mark Dery used the term "Afrofuturism" for the first time to describe the American music of experimental jazz musician and visionary Sun Ra (7), while in the DRC, this movement is known primarily through the visual arts. Dery defines the term "Afrofuturisum" in the following way:

Speculative fiction that treats African-American themes and addresses African-American concerns in the context of 2oth-century technoculture - and, more generally, African-American signification that appropriates images of technology and a prosthetically enhanced future.

ASZE K 41-42

More specifically, Kowdo Eshun explains in his article "Further Considerations of Afrofuturism" that Afrofuturism is a program that aims to recuperate the "counterfutures" created by Blacks "in a century hostile to the Afrodiaspora" (301). In brief, according to Eshun, Afrofuturist science fiction is not only a prophecy of the future but also a utopian method for putting into place "alternative social realities" by "a distortion of the present," and it is a way to "preprogram the present" (290). 
Similarly, in music, we can speak of Pierre Kwenders, the Afro-Canadian author/composer/performer, who is well established in Canada and known to be an innovator in futurist hip-hop. Born José Louis Modabi in Kinhasa, Kwenders came to Quebec as a boy in order to reunite with his mother. The magazine Les Inrockuptibles describes him in these terms: "The magic of Pierre Kwenders is located exactly here, multiplying registers without dissolving them, without confusing them" (Abreu 2017). Kwenders claims Afrofuturism for himself when he states that "Afrofuturism is a word that I invented to describe my music. I can escape neither my African roots nor Canadian multiculturalism. I lived in modernity, in the future, the electro" (Binet 2015).

In this very brief exploration of futurist networks in popular culture, painting must also be mentioned. For example, Masters of Congolese painting, such as Cheri Samba, were discovered during the 1989 exhibition at Beaubourg "Les Magiciens de la terre"; but it is also because these painters reflect upon the possibilities of the African continent that certain artists have become associated with Afrofuturism, as we can clearly see in the case of an artist like Monsengo Shula.

As for literature, Dery recalls how the science fiction imaginary is seemingly inherent in the condition of those of the African diaspora, as discussed in a 2019 interview:

Afrofuturism offers us an analytic prism to reread historical, canonical texts as though they were science fiction. Put on the glasses of Afrofuturism and reread The Invisible Man by Ralph Ellison (1952). It's a novel that takes its principal metaphor from science fiction and from horror stories, in the tradition of H.G. Wells. But it's equally a story that uses the conventions of Afrofuturism to articulate the condition of alienation and the almost extraterrestrial horror of being Black in America.

NICOLAS 2019

Africa is no different. Alain Vicky explains in a premonitory tone:

Far from the media's radar, a group of young African artists, grandchildren of Independence, Blacks and Whites, connected by blogs and by a handful of new pan-African magazines, are inciting a cultural revolution on the continent by occupying a territory until now reserved for Western imaginations, that of science fiction. To paraphrase the Senegalese philosopher Souleymane Bachir Diagne, on a continent where the way forward into the future is in doubt, the meaning comes from the future. 
Years later, Africa has developed this futuristic imagination in various media. Consider for example the trailer for 2035 Bataille, a science fiction film by Ken N'Siona, a digital editor and graphic designer ("Film congolais"). The plot is that a robot made by a young Congolese genius has been unleashed by a virus attacking its server, and then it decides in 2035 to destroy all of humanity. The attack begins in America, then moves to Africa and the DRC and Kinshasa.

From the era when the magazine Galaxies, ${ }^{3}$ specializing in the publication and criticism of speculative fiction, dedicated two of its issues (1988 and 2018) to African science fiction, or rather to social science fiction stories set in Africa, the landscape has evolved considerably - even if critics occasionally link Emmanuel Dongala's short story "Jazz et vin de palme" (1982) to speculative fiction, or, on the other side of the river, in the Congo, Brazzaville, to Sony Lab'ou Tansi's play Conscience de tracteur (1979), or to Albert Kapepa, for example, one of the first science fiction authors in the DRC. Born in Kinhasa in 1974, Kapepa's family is from eastern DRC. He spent his childhood in Lubumbashi, Katanga, where he went to law school. He has been a lawyer in Lubumbashi since 2006. He first published a short story called "Kihara, la pierre des ancêtres" in the edited volume Chroniques du Congo (2012), then wrote the social science fiction novels Titan, l'espace d'une dérive, Croisade inter-stellaire (2007), and Visa pour l'éternité (which remains unpublished). In "Kihara, la pierre des ancêtres," Kapepa writes:

History is nothing but a scam. We don't learn anything from it. It's nothing more than the voice of the conqueror. There are so many events that it has chosen to ignore, yet the ancestral, oral tradition has succeeded at conserving these over time.

"Kihara" 75

The writer's literary career is symbolic of new practices of writing and of distribution for the authors of popular modernity. Unlike writers of his preceding generation, Kapepa did not have a university or literary training. He is linked to the group Libr'Ecrire, affiliated to the Agence Future, which describes its mission in these terms:

3 Galaxies is a French science fiction magazine published first by Nuit et Jour from 1953 to 1959, then by Opta, from 1964 to 1977. The first series, from November 1953 to April 1959, consisted of 65 issues. The second series, from May 1964 to August 1977, consisted of 158 numbers (the August / September 1975 number being numbered 135/136). Galaxies nouvelle série was founded in 2008 . 
The Libr'Ecrire Collective has been active for many years in Lubumbashi. It doesn't have an exact founding date, but it emerges from a longstanding solidarity and collaboration among various writers and poets, storytellers and orators. Writers share their work in regularly scheduled meetings. They also organize public presentations of their work, which are read by actors, slam poets, or singers. When alone, they read aloud from their own texts. Membership isn't required, and there isn't a list of participants. Often, they work together in groups of a half dozen. But, on occasion, meetings can include ten, twenty, or thirty or more writers. Writers don't share a mother tongue and French, as a lingua franca, has an ambiguous position. Libr'Ecrire brings together authors who are quite diverse: three writers will help develop ideas for the future during activities with youth from Brussels and Lubumbashi.

"Collectif Libr' écrire"

As Salomon Ramcy Kabuya Ngoie explains in an article about the contemporary forms of literary expression in Lubumbashi, after the departure of the reputed writers Georges Ngal, V.Y. Mudimbe, Mukala Kadima Nzuji, and Pius Ngandu Nkashama:

Unlike several other literary structures in the city, Libr'Ecrire is unique in its interest in practice more than the theorization of literature (formerly practices by the Cellule littéraire or the Cercle littéraire rénové) and by its refusal of any restriction in genre or style.

67

Writing collectives, workshops, work being written or translated into in several languages, and multimedia practices - in short, much remains to be studied. Much remains to be done, not the least of which is to list on different platforms already published texts of social science fiction. Examples of this diversity include Lala Denamganaï's social science fiction novel Dieu, C'est le diable, hé Couillon! (2018), whose publication was announced in the newspaper Ouest-France (Belaud 2018). But we cannot end this summary without mentioning the writer who brought about Congolese popular literature, Zamenga Batukezanga. 
Zamenga Batukezanga has been widely studied and reviewed for many years. After his death, a literary prize was created in his name, but it was not until 1985 that the D RC (formerly Zaire) awarded him a literary prize. ${ }^{4}$ His entry in the Dictionnaire mondial des littératures reads as follows:

Born in the west of the country into a Protestant family, he converted to Catholicism, was trained as a social worker and began his career as an educator. Teacher, director of social work at the University of Kinshasa, defender of the rights of the handicapped, founder of a center dedicated to the rehabilitation of people with physical disabilities, Zamenga also advocated for what he believed in through writing. [...] Each of his 23 books sold tens of thousands of copies, and yet his work remained unknown outside of his country.

"Zamenga Batukezanga"

His books have sold over a million copies to date. ${ }^{5}$ From the standpoint of literary sociology, Batukezanga is a remarkable case of an author being promoted from the popular to the canon of cultural works. His texts are regularly republished, and it is amazing to see the continued pertinence of his oeuvre's themes: questions about sorcery, relations of the sexes, the place of sects and religions, but especially his humanist and spiritual engagement. MarieCatherine Mata Masala, in her 1993 dissertation "Zamenga Batukezanga et son œuvre," describes his success in these terms: "[Batukezanga] joins the ranks of authors who became famous because of their prolific literary work. This includes authors such as Eugène Sue, the 'king of popular novels'; Jorge Amado, the 'novelist of the people'; and, of course, the prodigious Felix Couchoro!" (247).

But it is in the connection to the world of comics that Batukezanga will allow us to transition to our final section. Batukezanga saw many of his texts adapted into comics by Editions Saint-Paul, including Un Croco à Luozi (1982) and Bandoki (1973). Very early on, Batukezanga understood the reasons for combining

4 He was awarded the Grand Prize of the Twentieth Anniversary of the Second Republic of Zaire for his career in the arts and letters.

5 His literary career is characterized by the quantity and the diversity of his texts, making him one of the most prolific Zairian writers in history. His works include twenty-three published stories, novels, essays, and collections of poems, three unpublished plays, and about forty articles published almost in their entirety in L'Étoile du Congo (later L'Étoile) from 1965 to 1972. See Mata Masala 1995 . 
text and image. In collaboration with Pat Masioni, he would publish nine comic books from 1987 to 2001, each published by the publishing house that he created, Zabat (a contraction of "Zamenga Batukezanga"), which later became Zola-Nsi. Batukezanga followed a well-thought-out strategy of distribution:

Comics offer to those of us who live in countries made up of populations that are mostly semi-literate the possibility of communicating and spreading messages and knowledge [...] while my texts have not yet been printed t in more than one or two editions, Un Croco à Luozi is now in its eighth edition.

La Littérature 19

In 2010, Cassiau-Haurie wrote the interesting Histoire de la BD congolaise, which provided history going back to the colonial era. In 2010 as well, the fiftieth anniversary of Congolese independence was celebrated in the comic book Congo 5o, published by Roularta Books and the Belgian not-for-profit organization Africalia. Congo 50 tells the story of twins Dipanda and Lipanda, a boy and a girl, baptized on June 30, 1960, the very day of the proclamation of national independence.

We know that the DRC quickly developed a rich tradition of comics, whether in Kinshasa, in Kinsangani, in the three provinces of Kivu (in the cities of Goma, Bukavu, and Kindu), or in Lubumbashi. Whether they were comics for children or adults, caricature sketches, or religious or political comics, all genres were present. We can even claim that the comic book industry in Congo is better established than the regular book industry. Because the comic book industry is part of a historical tradition with the outline of an institutional development and publications in publishing houses in Europe or in the Congo, we should not neglect all the publications distributed in informal circuits like sidewalk bookstores similar to the Onitsha market literature (Obiechima, 1972) in Nigeria. Véronique Bragard and Christophe Dony (2010) stated:

The expression of the Congolese postcolonial imagination in Belgium takes many forms, and perhaps not directly through traditional literary production. [...] The Congolese like many others Africans are the basis of a new tradition of comics, a medium at crossroads of social criticism, image, theater and orality, all important cultural elements.

92

As Cassiau-Haurie (2010) explained, comics first appeared in newspapers nationwide in 1921 and never stopped developing. Released in July 1931, the 
now controversial Hergé's Tintin in Congo and its success in Belgium encouraged Belgian colonial administrators to introduce comics to the Congolese who soon began to produce their own strips, a tradition that continues today despite political and economic vagaries. One can distinguish the works printed in color sometimes in co-edition with foreign publishers, Congolese publishing houses, collectives of authors who produce, distribute and sell their albums themselves, but also inexpensive pulps sold by peddling or on the steps. Certainly less expensive than the books sold in bookstores hence their success.

Moreover, today, due to the armed conflicts in the eastern parts of the country, many illustrators have moved to Kinshasa, where they continue to work, providing illustrations to the Kinshasa magazine Kin Label. ${ }^{6}$ Illustrators often create arts organizations to support one another and to see and learn from one another's art. ${ }^{7}$ In the Congo, comic books are supported as well by several prizes, including the Prix Africa Comics, organized by Africa e Mediterraneo and granted to Jason Kibiswa in 2008; or the Mongita d' or; and for others, the possibility of being published or co-published internationally. This is the case with Trésor Tshibangu Tshamala, who writes under the pseudonym Tetshim. ${ }^{8}$ While we can speak of the 1970s as the golden age of Congolese comic books, recent times have witnessed economic and political crises that have left illustrators facing many difficulties. For example, the Kin Label collective, a model organization, faces financial problems. Trésor Kibangula writes of this in an article published in Jeune Afrique:

The authors working under the banner of the platform Kin Label produce a black-and-white fanzine four times per year. It's impossible to expect anything more with the $\$ 4,100$ given to them to produce 2,000 copies for each issue. And yet, the magazine still doesn't sell well.

2013

6 As well as Asimba Bathy, noted illustrators include Jules Baïsole, Didier Kawende, Gédeon Mulamba, and Jason Kibiswa.

7 Twelve illustrators have formed the organization аввик (the Association des bédéistes de Bukavu, or the Organization of Comic Book Artists from Bukavu). Other groups include the UJADP/Erica, the Katanga, and the Vicanos Club, which meets in the Francophone Cultural Space of Lubumbashi.

8 Born in Kinshasa in 1980, he moved to Lubumbashi with his parents in 1991. He started composing the comic strip "La dot reportée" when he was sixteen years old, which had a goal of educating the public about AIDs. He became a journalist and caricature artist at the biweekly L'Etendard, at the weekly L'Essor du Katanga, as well as on a local television station, Mwangaza. In 2008, he received the Prix Spécial du Jury for a comic book competition sponsored by the Italian NGO Africa e Mediterraneo. Today, Tetshim is considered one of the most 
Illustrators have to be creative in order to get their work out and to sell it. Jason Kibiswa, a twenty-nine-year-old Kinshasa comic book writer, describes the situation:

The buying power of the Congolese is very weak. School kids prefer to buy a little bread or coca for themselves, rather than buy a book that costs 1,ooo Congolese francs [around 50 US cents]. We have to go promote our work. We propose to schools a day of drawing instruction, in which we teach students several ways of drawing. In the meantime, we try to sell our magazine. And, as a bonus, each kid who buys a magazine gets a free portrait done.

2013

Finally, this brief rundown must also include the publisher Elondja. Founded in 2004 by Dan Bomboko, this publishing house specializes in comic books. Bomboko addresses the means of promotion and distribution that were put in place to reach readers:

We use the Internet a lot, both Facebook and our blog, to reach readers and to tell them about our books. Elondja is also very active at book fairs and book expositions organized in Kinshasa so we can get in touch with our readership and promote our products.

GARY 2018

It will be necessary to work with institutions, such as the Kinshasa's Institut Français, the Centre Wallonie-Bruxelles, or the Bureau International de l'Edition Française (BIEF) and the Alliance internationale des éditeurs indépendants, in order to further develop the book market.

Yet, while many audiences recognize the quality of Congolese comic books, illustrators in the DRC struggle to make ends meet, and they must solicit copublishers and international partners in order to financially survive. Thembo Muhindo (Kash), published by L'Harmattan, had the opportunity in 2013 to present his last two comic books, Vanity and Jungle urbaine, at the Festival d'Angoulême. In 2016, the same Kash published Mbote Kinshasa, a comic book of fifty-six strips, in collaboration with the French Sébastien Maître as a writer.

remarkable illustrators in the new wave of Congolese comic book writers. See Cassiau-Haurie 2009 . 
The more recent rise of Jérémie Nsingi, the author of Tchoutchou et Miss Diva, exemplifies the tenacity necessary to make oneself known. A director of television advertisements and music videos, and a film editor, Nsingi is above all else a master of self-publication and self-distribution. He went all the way to China to find an affordable printer, ${ }^{9}$ and he sells his fanzines himself. He says:

[...] I was in contact with a retailer to whom I gave a number of copies, she would sell them and bring me my cut. This was a quick turnaround: a stock of 5 o copies would be sold in one or two days. Theoretically, this would mean 500 Congolese francs, or 70 US cents, per copy. I would make 30o, and she would 200. So, I wasn't sure if a book would sell at 500 because it is possible that the sale price was in fact higher. Impossible to know. The next Miss Diva, with 40 strips, will sell at $\$ 3$, so that everyone can buy it. I learned this strategy from the Chinese: sell a lot cheaply. I will build up printing gradually, but I hope to get to selling 50,000 copies, or even 100,000 in Kinshasa and at the different festivals I go to.

CASSIAU-HAURIE 2018

\section{$5 \quad$ Conclusion}

As we can see from these brief examples, popular literature is a complex, protean reality that asks its exponents to play the roles of publisher, distributor, and promoter, and to intimately know the public to which they address their works. Inventiveness, imagination, and originality are all called upon. The use of new technologies is indispensable. Living in an age of the global village which of course includes Africa - we must understand the resonance of the local preoccupations with the global. From Khemetism to love stories, from detective novels to popular novels and comic books, popular forms of art do what they do best: they hold up a population to the mirror while inviting them to open the pathways of the imagination. From this perspective, we must welcome new initiatives, such as that of the poet Harris Kasongo, who created the literary movement "Les Révoltés de la plume" in 2007 to compensate for the lack of infrastructure in the book professions in the DRC. In the commune of

9 Nsingi writes: "Prices there are really a lot less than you would think, and they have everything set up. The Congolese diaspora in China helps to find a place in shipping containers in order to deliver the magazines here. Thanks to this, we have good-quality comic books produced at a lower price than what is possible here, and that's even with shipping fees" (Cassiau-Haurie, 2018). 
Bandalungwa on the outskirts of Kinshasa, the Rebels launched several campaigns to sensitize young people to the importance of the contribution of writers in the development of a country. The movement brings together writers, thinkers, researchers, slammers, journalists, students, and musicians - in short, it brings together, as Harris Kasongo says, "lovers of reading and writing, around the promotion of literature in all its forms and defends the values of Francophonie" (Kivuila 2018).

In January 2021, "Les Révoltés de la plume" launched the Literary Star Prize, which will be awarded to the five best authors of the first issue of the review Feuille de route, a review that the group has created in order "to give a showcase to the Democratic Republic of Congo at the literary level because we are a little forgotten in the literary circle and to promote literary actors," as Harris Kasongo says (Kuzamba 2021). Because if there is no shortage of writers' vocations, the book industry remains deficient in the DRC. It is also about making reading a popular activity not only by developing a taste for books but also by making books affordable. This is what popular culture and literature are also made of.

\section{Translated from the French by Matt Reeck}

\section{Works Cited}

Abreu Maxime de. "Pierre Kwenders continue d'inventer l'anti-world music." Les Inrockuptibles. 8 Sep. 2017. https://www.lesinrocks.com/musique/pierre-kwenders -continue-dinventer-lanti-world-music-113729-08-o9-2017/. 20 May 2021.

Barber, Karin. A History of African Popular Culture. Cambridge: Cambridge UP, 2018.

Bathy, Asimba, et al. Congo 5o. Brussels: Roularta Books/Africalia, 2010.

Batukezanga, Zamenga. Bandoki. Kinshasa: Editions Saint-Paul, 1973.

Batukezanga, Zamenga. Un Croco à Luozi. Kinshasa: Editions Saint-Paul, 1982.

Batukezanga, Zamenga. La Littérature en Afrique: pour une démystification. Kinshasa: Zabat, 199o.

Belaud, Julien. "Sablé-sur-Sarthe. Un roman d'anticipation entre Europe et Afrique." Ouest-France. 6 Mar. 2018. Web. 25 Apr. 2021.

Binet, Stéphanie. "Pierre Kwenders, chantre de l' afro-futurisme." Le Monde. 3 Apr. 2015. Web. 4 May 2021.

Bragard, Véronique and Christophe Dony. "Congostrip, la bande dessinée congolaise." La revue nouvelle 7/8 (2010). Web. 20 Apr. 2021.

Casanova, Pascale. La République mondiale des Lettres. Paris: Seuil, 1999.

Cassiau-Haurie, Christophe. "Littérature en RDC: la traversée du désert." Africultures. 3 Oct. 2007. Web. 24 Apr. 2021. 
Cassiau-Haurie, Christophe. Histoire de la BD congolaise. Paris: L'Harmattan, 2010.

Cassiau-Haurie, Christophe. "BD: Jérémie Nsingi à la conquête du marché international." Africultures. 17 May 2018. Web. 8 Apr. 2021.

Cassiau-Haurie, Christophe. "Dessinateurs de République Démocratique du Congo: à l'Est également." вD Zoom.com. 26 Feb. 20o9. Web. 11 Nov. 2020.

Chanda, Tirthankar. "La littérature africaine d'expression française: les années fastes." RFI. 4 Jan. 2019. Web. 3 Apr. 2021.

Damrosch, David. What Is World Literature? Princeton: Princeton UP, 2003.

Denamganaï, Lala. Dieu, C'est le diable, hé Couillon! Saint-Denis: Publibook, 2018.

Dery, Mark. Black to the Future, Flame Wars: The Discourse of Cyberculture. Durham: Duke UP, 1994 .

Dongala, Emmanuel. Jazz et vin de palme et autres nouvelles. Paris: Hatier, 1982.

Eshun, Kowdo. "Further Considerations of Afrofuturism." The New Centennial Review 3:2 (2003), 287-302.

Garnier, Xavier. “Modernités littéraires en Afrique: injonction ou évidence?" Itinéraires 3 (2009), 89-101.

Gary, Nicolas. "Elondja: le défi de l' édition de bandes dessinées au Congo." ActuLité. 10 Sept. 2018. Web. 8 Nov. 2020.

Glissant, Édouard. Traité du tout-monde, Poétique IV. Paris: Gallimard, 1997.

Goethe, Johann Wolfgang von. Sämtliche Werke, Briefe, Tagebücher und Gespräche. Eds. Friedmar Appel and Henrik Birus. Francfort-am-Mainz: Deutscher Klassiker Verlag, Vol. 22, 1999 .

Hélène. “Rencontre Babélio avec Janis Otsiemi." Lecturissime (blog), 19 Mar. 2017. http:// www.lecturissime.com/2017/o3/rencontre-avec-janis-otsiemi.html. 3 Dec. 2021

Izuwa. "La littérature underground africaine." Lettres noires. 27 Dec. 2018. https://lettres noires.com/focus-la-litterature-underground-africaine/. 3 Nov. 2020.

Kuzamba, Emmanuel. "Les révoltés de la plume." Actualité.cd. 15Jan. 2021. Web. 30 Apr. 2021.

Kabuya Ngoie, Salomon Ramcy. "Écritures urbaines lushoises." Études littéraires africaines 27 (2009), 65-73.

Kapepa, Albert. “Kihara, la pierre des ancêtres.” In Chroniques du Congo. Saint-Maurdes-Fossés, Éditions Sépia; Lubumbashi: Picha asbl, 2012, 23-39.

Kapepa, Albert. Chroniques du Katanga. Ed. Dominique Ranaivoson. Saint-Maur-desFossés: Éditions Sépia; Lubumbashi: Association La Halle de l'Étoile, 2007.

Kash and Sébastien Maître. Mbote Kinshasa. Saint-Avertin: La Boite à bulles, 2016.

Kibangula, Trésor. “Comment va la BD made in Kin?” Jeune Afrique. 16 Aug. 2013. Web. 8 Nov. 2020.

Kivuila, Cinardo. "Harris Kasongo: Élections à la Francophonie." Eventsrdc.com. 6 Oct. 2018. Web. 3 o Apr. 2021.

Lab'ou Tansi, Sony. Conscience de tracteur. Yaoundé: CLE, 1979. 
Lamping, Dieter. Die Idee der Weltliteratur. Ein Konzept Goethes und seine Karriere. Stuttgart: Kröner, 2010.

Mata Masala, Marie-Catherine. "Zamenga Batukezanga: Anatomie d'un succès populaire." Matatu 13-14:1 (1995), 241-48.

Mata Masala, Marie-Catherine. Zamenga Batukezanga. 1994. Université de Paris 3, PhD dissertation.

Moretti, Franco. “Conjectures on World Literature.” New Left Review 1 (2000), 54-68.

Müller, Gesine. "La littérature mondiale comme stratégie?" Revue germanique internationale 19 (2014), 65-79.

Naudillon, Françoise. "Black Polar." Présence Francophone: Revue internationale de langue et de littérature 60.1 (2003).

Newell, Stephanie and Onookome Okome. Popular Culture in Africa: The Episteme of the Everyday. London: Routledge, 2013.

Ndione, Abasse. La Vie en spirale. Paris: Gallimard, 1998.

Nicolas, C. "L' afrofuturisme se transforme en une mode pour hipsters." Usbek \& Rica. 6 Jan. 2019. Web. 4 Dec. 2020.

Obiechima, Emmanuel. Onitsha Market Literature. Heinemann: African Writers Series, 1973.

Otsiemi, Janis. Tu ne perds rien pour attendre. Paris: Éditions Plon, 2017.

Said, Edward. Orientalism. London: Penguin Classics, 1978.

Vicky, Alain. "Afrique, présence des futurs." Le Monde diplomatique 711 (2013), 27.

Yaszek, Lisa. "Afrofuturism, Science Fiction, and the History of the Future." Socialism and Democracy 20:3 (2006), 41-6o.

"Collectif Libr' écrire." Agence Future. n.d. http://www.agencefuture.org/?q=content/ collectif-librécrire.10. Apr. 2021.

"Film congolais science fiction 3D." Youtube, uploaded by Ken Nsiona, 22 Fev 2016, https://www.youtube.com/watch?v=AaRrqsKbaco. 3 Nov. 2020.

"Meilleures ventes roman africain." Fnac, https://livre.fnac.com/l192878/Meilleures-ven tes-Roman-Africain/Roman-Africain/Romanetranger/Roman-et-Nouvelles. 31 Apr. 2021.

"Zamenga Batukezanga." Dictionnaire mondial des littératures. Eds. Pascal Mougin and Karen Haddad-Wotling. Paris: Larousse, 2002. 